\title{
Article \\ Influence of Humic Acid on the Transport of Two Types of Synthesized Zinc Oxide Nanoparticles in Quartz Sand
}

\author{
Donghyun Kim and Gukhwa Hwang *
}

check for updates

Citation: Kim, D.; Hwang, G. Influence of Humic Acid on the Transport of Two Types of Synthesized Zinc Oxide Nanoparticles in Quartz Sand. Appl. Sci. 2021, 11, 8957. https://doi.org/10.3390/app11198957

Academic Editor: Chong Hyun (Paul) Chang

Received: 2 September 2021 Accepted: 24 September 2021 Published: 26 September 2021

Publisher's Note: MDPI stays neutral with regard to jurisdictional claims in published maps and institutional affiliations.

Copyright: (c) 2021 by the authors. Licensee MDPI, Basel, Switzerland. This article is an open access article distributed under the terms and conditions of the Creative Commons Attribution (CC BY) license (https:// creativecommons.org/licenses/by/ $4.0 /)$.
Department of Mineral Resources and Energy Engineering, Jeonbuk National University, Jeonju 54896, Korea; nighteast@jbnu.ac.kr

* Correspondence: ghhwang0920@gmail.com; Tel.: +82-63-219-5543

\begin{abstract}
In this study, transport and retention behaviors of the two types of $n \mathrm{ZnO}$ prepared with separate manufacturing methods were compared/analyzed according to the presence/absence of Suwannee River humic acid (SRHA) adsorbed into the sand surface and the SRHA suspended in bulk solution, and to changes in the solution ionic strength (0.1-10 $\mathrm{mM})$ in sand-repacked water-saturated columns. In the absence of suspended SRHA, $n \mathrm{ZnO}-1$ breakthrough was observed only in SRHAcoated soil, and the breakthrough amount decreased with the increase in the ionic strength $(23.8 \%$ to $17.2 \%$ at $0.1 \mathrm{mM}$ to $10 \mathrm{mM}$, respectively). In contrast, $n \mathrm{ZnO}-2$ breakthrough was not observed over the entire ionic strength range, regardless of the SRHA sand coating. With the presence of suspended SRHA, neither $n \mathrm{ZnO}-1$ nor $n \mathrm{ZnO}-2$ showed a significant difference in the breakthrough amount regardless of sand coating or ionic strength. However, the breakthrough amount of $n \mathrm{ZnO}-1$ was higher than that of $n \mathrm{ZnO}-2$ (51.5\% versus $37.7 \%$ at $10 \mathrm{mM}$ with $1 \mathrm{mg} / \mathrm{L} \mathrm{SRHA})$. From confirming the difference in transport between the two types of $n \mathrm{ZnO}$, the amount of SRHA adsorbed into $n \mathrm{ZnO}-1$ was less than the amount adsorbed into $n \mathrm{ZnO}-2(0.29 \mathrm{mg} / \mathrm{g}$ versus $0.64 \mathrm{mg} / \mathrm{g}$ at $10 \mathrm{mM}$ with $1 \mathrm{mg} / \mathrm{L}$ SRHA). This result was considered to be due to the larger $n \mathrm{ZnO}-1$ breakthrough amount than the $n \mathrm{ZnO}-2$ breakthrough amount, which was caused by the larger amount of suspended SRHA that could occupy the deposition sites in the $n \mathrm{ZnO}-1$ suspension. Because the rate of SRHA deposition on the sand surface was higher than on $n \mathrm{ZnO}, n \mathrm{ZnO}$ transport improved in the presence of suspended SRHA, and changed according to the amount of suspended SRHA.
\end{abstract}

Keywords: zinc oxide nanoparticles; humic acid; transport; retention; deposition site competition

\section{Introduction}

Metal oxide nanomaterials are widely used in industrial settings [1-4]. In particular, zinc oxide nanoparticles ( $\mathrm{ZnO}-\mathrm{NPs}$ ) are used widely in the fields of cosmetics, optics, and the chemical industry [5,6] due to their multifunctional properties, and also for nanocomposite development [7]. Adverse effects of ZnO-NPs on living organisms have been reported frequently, e.g., [8-15]. For example, the toxicity of ZnO-NPs in plants [10,11], bacteria [8,16], and rodents [17] has been reported. The environment has been exposed more and more to $\mathrm{ZnO}-\mathrm{NPs}$ with the increase in the demand for and production of $\mathrm{ZnO}-$ NPs. For detailed and accurate analyses on the risk of ZnO-NPs, their exposure probability must be evaluated, and studies on their fate and transport must be conducted [1].

Studies on the fate and transport of $\mathrm{ZnO}-\mathrm{NPs}$ have been conducted in various soil environment conditions, such as flow rate, ionic strength, $\mathrm{pH}$, ion valence, and type of porous media, which have been shown to be important factors in nanoparticle transport behavior, e.g., [4,18-24]. Humic acid has been reported to improve the ZnO-NPs transport level in the soil environment $[14,16]$, and one of the main mechanisms causing such trend was confirmed as deposition site competition between natural organic matter (NOM) and nanoparticles [25]. These studies on $\mathrm{ZnO}-\mathrm{NPs}$ transport have targeted single particles. Although variously synthesized particles were used in previous studies on ZnO-NPs fate and transport, comparisons among their outcomes may not be appropriate due to the 
differences in the soil environment conditions, such as flow rate, ionic strength, $\mathrm{pH}$, ion valence, and porous media. Although ZnO-NPs are known to be synthesized by various methods [26,27], no comparative studies on the fate and transport behavior of ZnO-NPs synthesized with diverse methods have been reported so far. In our recent comparative study [28], ZnO-NPs synthesis methods were confirmed to affect the physicochemical properties (particle size, surface functional groups, specific surface area, and particle shape) of $\mathrm{ZnO}-\mathrm{NPs}$. Significant differences in their properties, which affected the aggregation and dissolution tendencies of the two types of $\mathrm{ZnO}-\mathrm{NPs}$, were also confirmed [28].

It should be noted that the physicochemical properties of nanoparticles have been reported to be critical factors affecting their fate and transport $[4,29,30]$. Thus, it is reasonable to expect that the nanoparticles synthesized with different approaches could show different transport behavior, but no comparative studies on this issue have been reported; thus, the relevant study is required.

The first objective of this study was to compare/analyze the transport and retention behaviors of the two types of commercial ZnO-NPs, which were prepared with different methods, in saturated porous media as a function of the presence/absence of the SRHA that is present in the soil media surface and the SRHA that is present in the bulk solution, and to changes in the ionic strength. The second objective of this study was to reverify the deposition site competition that was reported as the mechanism of the coexistence of recently-reported suspended SRHA and NPs in the soil environment using two types of the ZnO-NPs that were synthesized by different methods, and eventually to enhance the reliability of the suggested mechanisms of $\mathrm{ZnO}-\mathrm{NPs}$.

\section{Materials and Methods}

\subsection{ZnO-NPs Suspension Preparation}

$\mathrm{ZnO}-\mathrm{NPs}$ can be synthesized via various approaches (e.g., precipitation, spray pyrolysis, hydrothermal synthesis, solvothermal synthesis, electrochemical methods, sol-gel, microwave synthesis, and green synthesis) [31-33]. Among those, a chemical precipitation method with different synthesis conditions, which was modified from published procedures $[26,27,34]$, was used to prepare $\mathrm{ZnO}-\mathrm{NPs}$ in the present study. The synthesis processing of $\mathrm{ZnO}-\mathrm{NPs}$ is described in the Supplementary Information. The synthesized $\mathrm{ZnO}-\mathrm{NP}$ samples from synthesis 1 and synthesis 2 were designated as $n \mathrm{ZnO}-1$ and $n \mathrm{ZnO}-2$, respectively. The $n \mathrm{ZnO}$ stock suspensions $\left(100 \mathrm{mg} \mathrm{L}^{-1}\right)$ were prepared by dispersing the $n \mathrm{ZnO}$ in Milli-Q water (Q-Gard, Millipore Inc., Billerica, MA, USA). To enhance dispersibility, ultrasound (ultrasonic homogenizer, KNSN-RAB, KOEN, South Korea) was applied for $30 \mathrm{~min}$. A stock suspension was prepared each time prior to an experiment and was diluted in the desired salt solution $(\mathrm{NaCl}, 0.1,1$, and $10 \mathrm{mM})$ to prepare the $n \mathrm{ZnO}$ input suspension $\left(20 \mathrm{mg} \mathrm{L}^{-1}\right)$ that was necessary for column tests. Then, the $n \mathrm{ZnO}$ suspension was stirred for $2 \mathrm{~h}$ at $200 \mathrm{rpm}$ to adjust its $\mathrm{pH}$ to 9.0 using $0.1 \mathrm{M} \mathrm{NaOH}$.

\section{2. $\mathrm{ZnO}-\mathrm{NPs}$ Characterization}

X-ray diffraction (XRD) patterns were recorded with a Bruker D8 HRXRD X-ray diffractometer using Ni-filtered $\mathrm{Cu} \mathrm{K} \alpha$ radiation $(\lambda=0.154606 \mathrm{~nm}, 40 \mathrm{kV}, 40 \mathrm{mV})$. XRD patterns of the samples were collected in the range of $20-65^{\circ}(2 \theta)$ with a step size of $0.02^{\circ}$ and step time of $2 \mathrm{~s}$. Transmission electron microscope (TEM) observations were conducted with JEOL-2010F microscope operated at $200 \mathrm{kV}$. The samples for TEM measurements were suspended in ethanol and dropped onto holey carbon films that were supported on $\mathrm{Cu}$ grids for imaging. The specific surface areas of the samples were determined via gas physisorption at $-196{ }^{\circ} \mathrm{C}$ using a Micromeritics ASAP 2020M analyzer and assessed from nitrogen adsorption data in the partial relative pressure from 0.05 to 0.25 using the Brunauer-Emmett-Teller (BET) method [34,35]. The zeta potential and particle size of $n \mathrm{ZnO}$ with the presence/absence of SRHA ( 1 and $5 \mathrm{mg} \mathrm{L}^{-1}$ as TOC concentration) in the $\mathrm{NaCl}(0.1,1$, and $10 \mathrm{mM})$ solution were measured using ELS-Z (Otsuka, Osaka, Japan); the measurements were conducted 10-15 times repeatedly and immediately prior 
to the column test at room temperature $\left(25^{\circ} \mathrm{C}\right)$. The zeta potential was converted from measured electrophoretic mobility values using the Smoluchowski equation, and the particle size was determined using a dynamic light scattering (DLS) method [36,37]. The zeta potential and particle size of the two types of $n \mathrm{ZnO}$, which were measured in $\mathrm{NaCl}$ in the presence/absence of SRHA and according to the ionic strength, are shown in Figure 1.

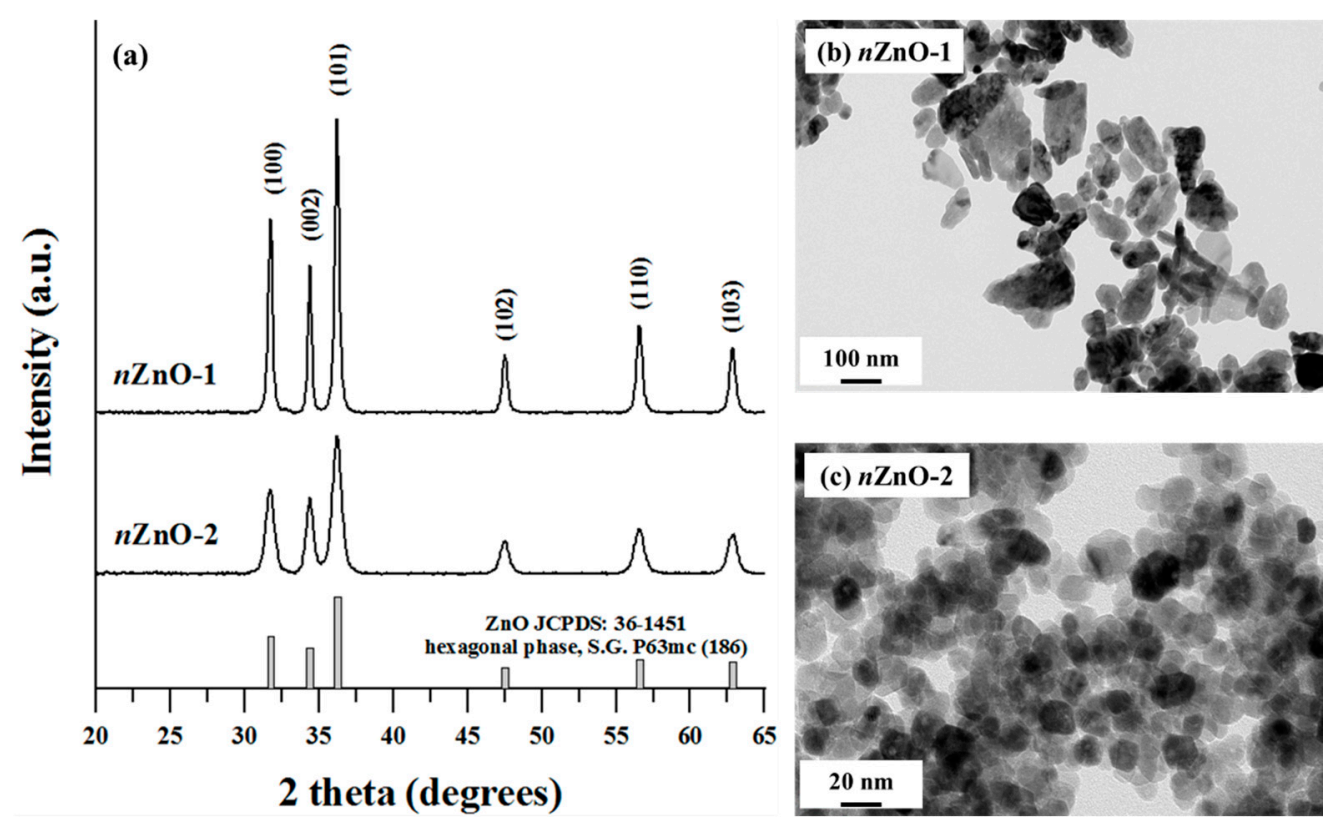

Figure 1. (a) XRD patterns of the synthesized $n \mathrm{ZnO}$ obtained from synthesis 1 of $n \mathrm{ZnO}-1$ and synthesis 2 of $n \mathrm{ZnO}-2$. TEM images of the synthesized $n \mathrm{ZnO}$ obtained from synthesis 1 (b) $n \mathrm{ZnO}-1$ and synthesis 2 (c) $n \mathrm{ZnO}-2$.

\subsection{Suwannee River Humic Acid (SHRA) Solution Preparation}

In this study, humic substances, which are abundant in the freshwater environment, were used as an NOM. SRHA (Cat. \#2S101H, International Humic Substances Society), which is used frequently in colloid transport studies, was used as a humic substance. The SRHA stock solution was prepared according to a method reported previously $[15,19]$. First, $25 \mathrm{mg}$ of dried SRHA was placed into $50 \mathrm{~mL}$ Milli-Q water (Q-Gard) and was stirred for $24 \mathrm{~h}$. The solution was filtered using a $0.22 \mu \mathrm{m}$ filter, and its $\mathrm{pH}$ was adjusted to 8.0 using $0.1 \mathrm{M} \mathrm{NaOH}$. This filtered and $\mathrm{pH}$-adjusted solution was kept in a darkroom at $4{ }^{\circ} \mathrm{C}$ to be used as the SRHA stock solution. The concentration of the SRHA stock solution was analyzed using a TOC meter (TOC-VCPH, Shimadzu Co., Kyoto, Japan), the median diameter of which was $\sim 475 \mu \mathrm{m}$, and the uniformity factor 1.5 . The porous media were cleansed to remove chemical heterogeneity using the method suggested in previous studies [38,39]; the soil media were placed into Milli-Q water and shaken to remove impurities, then soaked in $37 \% \mathrm{HCl}$ at 1:1 ratio for $24 \mathrm{~h}$. The media were cleaned again with Milli-Q water, and the above process was repeated one more time before baking them at $800{ }^{\circ} \mathrm{C}$ for $8 \mathrm{~h}$. To rehydrate the baked soil media prior to the column test, they were placed into Milli-Q water and boiled for at least $1 \mathrm{~h}$. The zeta potential was measured at the desired $\mathrm{NaCl}$ solution ionic strength after the soil media were ground.

Column experiments were conducted with $\mathrm{NaCl}$ as a salt at various ionic strengths, ranging from $0.1 \mathrm{mM}$ to $10 \mathrm{mM}$. The transport and retention behaviors of the two types of $n \mathrm{ZnO}$ were compared and analyzed. Cleansed sand was wet-packed in the cylindrical glass chromatography column $(10 \mathrm{~cm}$ in length $\times 2.5 \mathrm{~cm}$ in inner diameter (Omnifit, UK)). The wet sand was packed little by little (at an interval of $\sim 1 \mathrm{~cm}$ ) with a slight wobble and layering or minimal air inflow. The porosity of the packed column was measured at 0.36 .

After packing, deionized water (DI) was supplied for 10 pore volumes (PV, defined as $\mathrm{t} / \mathrm{V}$; here, $\mathrm{t}, \mathrm{V}$, and $\mathrm{Q}$ represent time, column void volume, and volumetric flow rate) 
to remove impurities in the column, and the $\mathrm{NaCl}$ set at the desired ionic strength and $\mathrm{pH}$ was injected for at least $10 \mathrm{PV}$ to reach an equilibrium prior to the experiment. Upon completion of equilibration, the $n \mathrm{ZnO}$ suspension with or without SRHA was injected for $5 \mathrm{PV}$. Then, particle-free $\mathrm{NaCl}$ with the same ionic strength and $\mathrm{pH}$ was injected for $5 \mathrm{PV}$. The $n \mathrm{ZnO}$ and salt solution were injected in up-flow mode using a peristaltic pump (Cole-Parmer, Thermo Fisher Scientific, Waltham, MA, USA). The concentration of the injected $n \mathrm{ZnO}$ suspension was $20 \mathrm{mg} \mathrm{L}^{-1}$. All the flow rates in the experiments were set at $1.144 \mathrm{~mL} \mathrm{~min}^{-1}$. The $n \mathrm{ZnO}$ released from the column were continuously $(\sim 8 \mathrm{~mL})$ sampled in a $10 \mathrm{~mL}$ test tube. To investigate the distribution of the retained NPs in the column, the column was dissected at approximately every $1 \mathrm{~cm}$ after the transport experiment, and soil media were placed into $0.5 \mathrm{M} \mathrm{HNO}_{3}$ to dissolve $n \mathrm{ZnO}$. The concentrations of the $n \mathrm{ZnO}$ released from the column and the $n \mathrm{ZnO}$ retained in the column were analyzed using ICP. The areas below the breakthrough curves represent the relative concentration of the $n \mathrm{ZnO}$ released from the column against the concentration of the $n \mathrm{ZnO}$ that was injected initially. The obtained retention profiles represent the fraction (i.e., retained $n \mathrm{ZnO}$ amount/total injected $n \mathrm{ZnO}$ amount) of the $n \mathrm{ZnO}$ retained in the unit mass of the soil media. The whole collected $n \mathrm{ZnO}$ fraction obtained from the breakthrough curve and retention profile are shown in Table S2 (mass balance).

\subsection{SRHA Adsorption Experiments for $\mathrm{ZnO}-\mathrm{NPS}$}

Previous studies reported that SRHA can adsorb onto the surface of $\mathrm{ZnO}-\mathrm{NPs}$ and alter the surface properties $[15,28]$. Based on the procedure described in the previous studies, the amounts of SRHA adsorbed into the two types of $n \mathrm{ZnO}$ as a function of the ionic strengths $(0.1 \mathrm{mM}$ and $10 \mathrm{mM})$ were evaluated at $\mathrm{pH}$ 9. The initial SRHA concentrations were set at $1 \mathrm{mg} \mathrm{L}^{-1}$ and $5 \mathrm{mg} \mathrm{L}^{-1}$, and the added $n \mathrm{ZnO}$ suspension concentration was set at $20 \mathrm{mg}$ $\mathrm{L}^{-1}$. $n \mathrm{ZnO}$ and SRHA were stirred for $30 \mathrm{~min}$ to facilitate adsorption. Upon completion of adsorption, the $n \mathrm{ZnO}$ suspension was placed into a $50 \mathrm{~mL}$ tube to centrifuge (20 min, $15,000 \times g ; 1580 \mathrm{MGR}, \mathrm{Gyrozen}$, South Korea). Then, $2 \mathrm{~mL}$ of supernatant was carefully collected from each tube. The collected samples were put in a $15 \mathrm{~mL}$ tube to centrifuge again $(20 \mathrm{~min}, 15,000 \times g) . n \mathrm{ZnO}$ and SRHA were separated completely. Initial and final SRHA concentrations were measured at $254 \mathrm{~nm}$ using a spectrophotometer [28] (HS-3300, Humas, South Korea). The results of the experiments in each condition were expressed as $\mathrm{mg}$ SRHA/g $n \mathrm{ZnO}$.

\subsection{Derjaguin-Landau-Verwey-Overbeek (DLVO) Interaction Energy Calculation}

To confirm the details of $n \mathrm{ZnO}$ transport behaviors in the presence/absence of SRHA, through the column experiments, the total interaction energy of NPs-NPs and quartz-NPs according to the distance was calculated using the classic DLVO theory. As shown in Equation (1), the DLVO interaction energy was calculated as the sum of retarded van der Waals energies $\left(\Phi_{V D W}\right)$ and electrostatic double layer energies $\left(\Phi_{E D L}\right)$.

$$
\Phi_{\text {Total }}=\Phi_{V D W}+\Phi_{E D L}
$$

In $\Phi_{V D W}$, a sphere-sphere equation was used for NPs-NPs, and a sphere-plate equation for NPs-sand. Each equation is expressed as Equations (2) and (3) [40].

$$
\begin{gathered}
\Phi_{V D W-S S}=-\frac{A_{131} a_{p 1} a_{p 2}}{6 h\left(a_{p 1}+a_{p 2}\right)}\left[1-\frac{5.32 h}{\lambda} \ln \left(1+\frac{\lambda}{5.32 h}\right)\right]^{-1} \\
\Phi_{V D W-S P}=-\left\{\frac{A_{131} a_{p}}{6 h}\right\}\left[1+\left(\frac{14 h}{\lambda}\right)\right]^{-1}
\end{gathered}
$$

where $a_{p 1}$ and $a_{p 2}$ in Equation (2) refer to the radii of the two interacting spherical NPs, whereas $a_{p 1}$ in Equation (3) refers to the radius of the NPs, h represents the distance between the two NPs (Equation (2)) or the distance between NPs and sand surface (Equation (3)), 
and $A_{131}$ is the Hamaker constant. In the NPs-water-NPs system, $1.23 \times 10^{-20} \mathrm{~J}$ was used in the absence of SRHA, and $6.09 \times 10^{-22} \mathrm{~J}$ in the presence of SRHA. $A_{132}$ is the Hamaker constant in the NPs-water-collector system; it was calculated at $6.96 \times 10^{-21} \mathrm{~J}$ in the absence of SRHA, and $1.54 \times 10^{-21} \mathrm{~J}$ in the presence of SRHA. The combined Hamaker constant NPs-water-NPs system $\left(A_{131}\right)$ and NPs-water-sand system $\left(A_{132}\right)$ were calculated through Equations (4) and (5), respectively.

$$
\begin{gathered}
A_{132}=\left(\sqrt{A_{11}-A_{33}}\right)\left(\sqrt{A_{22}-A_{33}}\right) \\
A_{131}=\left(\sqrt{A_{11}-A_{33}}\right)^{2}
\end{gathered}
$$

$A_{11}$ is the Hamaker constant for $n \mathrm{ZnO}$, and $9.21 \times 10^{-20} \mathrm{~J}$ was used [41]. In the presence of SRHA, $4.71 \times 10^{-20} \mathrm{~J}$ was used for the Hamaker constant of $n \mathrm{ZnO}$ with adsorbed SRHA [42]. $A_{22}$ was the Hamaker constant for silica, and $6.50 \times 10^{-20} \mathrm{~J}$ was used, from [43]. $A_{33}$ was the Hamaker constant for water, and $3.70 \times 10^{-20} \mathrm{~J}$ was used same as $A_{22}$, considering [43]. $\lambda$ was the characteristic wavelength adsorbed in the interaction, and $100 \mathrm{~nm}$ was typically used. Initial particle sizes measured prior to transport experiments were used in Equations (2) and (3). Adsorption of SRHA on the surface of nanoparticles could stabilize the nanoparticles in suspension and alter particles size of nanoparticles, obtaining a different $a_{p}$ used in Equation (3).

To calculate $\Phi_{E D L}$, NPs-NPs was assumed to have had a sphere-sphere form, and NPs-sand, a sphere-plate form. Each equation is shown as Equations (6) and (7) [44].

$$
\begin{gathered}
\Phi_{E D L-S S}=\frac{2 \pi a_{p 1} a_{p 2} n_{\infty} k T}{\left(a_{p 1}+a_{p 2}\right) \kappa^{2}}\left(\phi_{p 1}^{2}+\phi_{p 2}^{2}\right)\left\{\frac{2 \phi_{p 1} \phi_{p 2}}{\phi_{p 2}^{2}+\phi_{p 2}^{2}} \ln \left[\frac{1+\exp (-\kappa h)}{1-\exp (-\kappa h)}\right]+\ln [1-\exp (-2 \kappa h)]\right\} \\
\Phi_{E D L-S P}=\pi \varepsilon_{0} \varepsilon_{r} a_{p}\left\{2 \psi_{p} \psi_{c} \ln \left[\frac{1+\exp (-\kappa h)}{1-\exp (-\kappa h)}\right]+\left(\psi_{p}^{2}+\psi_{c}^{2}\right) \ln [1-\exp (-2 \kappa h)]\right\} \\
\kappa=\sqrt{\frac{e^{2} \sum n_{i 0} z_{i}^{2}}{\varepsilon_{0} \varepsilon_{r} k T}}
\end{gathered}
$$

$n_{\infty}$ denotes the bulk number density of ions $\left(\mathrm{N} \mathrm{m}^{-3}\right.$, where $\mathrm{N}$ is the number $), k$ is the Boltzmann constant $\left(\mathrm{J} \mathrm{K}^{-1}\right), T$ the absolute temperature of the system $(\mathrm{K}), \varphi_{p 1}$ and $\varphi_{p 2}$ are the zeta potentials of NPs 1 and $2(\varphi=\mathrm{ze} \psi / k T)$, and $\psi_{p}$ and $\psi_{c}$ are the zeta potentials of the nanoparticle and sand $(\mathrm{V})$, respectively. $\varepsilon_{0}$ represents the permittivity of a vacuum $\left(\mathrm{C} \mathrm{V}^{-1} \mathrm{~m}^{-1}\right), \varepsilon_{r}$ the dielectric constant or relative permittivity of water, $\kappa$ represents the Debye-Hückel reciprocal length $\left(\mathrm{m}^{-1}\right) . z_{i}$ is the ion valence, $e$ is the electron charge $(C)$, and $n_{i 0}$ represents the number concentration of the $i$ ions in the bulk solution. The zeta potential and particle size values that were used for calculating DLVO interaction energies are shown in Table S1.

\section{Results and Discussion}

\subsection{Characterization of Prepared Two Types of $\mathrm{ZnO}-\mathrm{NPS}$}

The XRD and TEM analysis results for the $n \mathrm{ZnO}$ prepared by two different synthesis methods are presented in Figure 1, and the key properties are also summarized in Table 1. Overall, two $n \mathrm{ZnO}$ was observed to exhibit different physical properties, and the detailed information on all properties for two $n \mathrm{ZnO}$ is provided in the Supplementary Information. Figure 2 shows the results of the zeta potential and DLS particle size of the two types of $n \mathrm{ZnO}$ as a function of the change in SRHA concentration and ionic strength at $\mathrm{pH} 9$. Note that zeta potential represents the electrical potential of a particle measured at slipping plane, and the value is affected by many variables (e.g., salt type, salt concentration, polymer sorption, $\mathrm{pH}$ ) [45]. In the absence of SRHA (Figure $2 \mathrm{a}, \mathrm{b}$ ), the zeta potential of $n \mathrm{ZnO}-1$ was less negative than that of $n \mathrm{ZnO}-2$ over the whole ionic strength range $(0.1-10 \mathrm{mM})$, 
showing no difference as a function of the change in the ionic strength $(0.1-10 \mathrm{mM})$; and the zeta potential of $n \mathrm{ZnO}-2$ was formed at approximately the isoelectric point (IEP) in the whole ionic strength range $(0.1-10 \mathrm{mM})$. In the presence of SRHA, the zeta potential for two types of $n \mathrm{ZnO}$ was more negative than that in the absence of SRHA, showing a consistent tendency over the whole ionic strength range $(0.1-10 \mathrm{mM})$, regardless of the SRHA concentration changes ( 1 and $5 \mathrm{mg} \mathrm{L}^{-1}$ ). With the presence of SRHA, no difference in the zeta potential was observed between the two types of $n \mathrm{ZnO}$. The reason for the more negative charge in the zeta potential in the presence of SRHA was that the small amount ( 1 and $5 \mathrm{mg} \mathrm{L}^{-1}$ ) of SHRA added in the solution was adsorbed into the $n \mathrm{ZnO}$ to accelerate the change. This has been reported previously; SRHA was adsorbed onto metal oxide NPs to negatively increase the zeta potential [19,46-49].
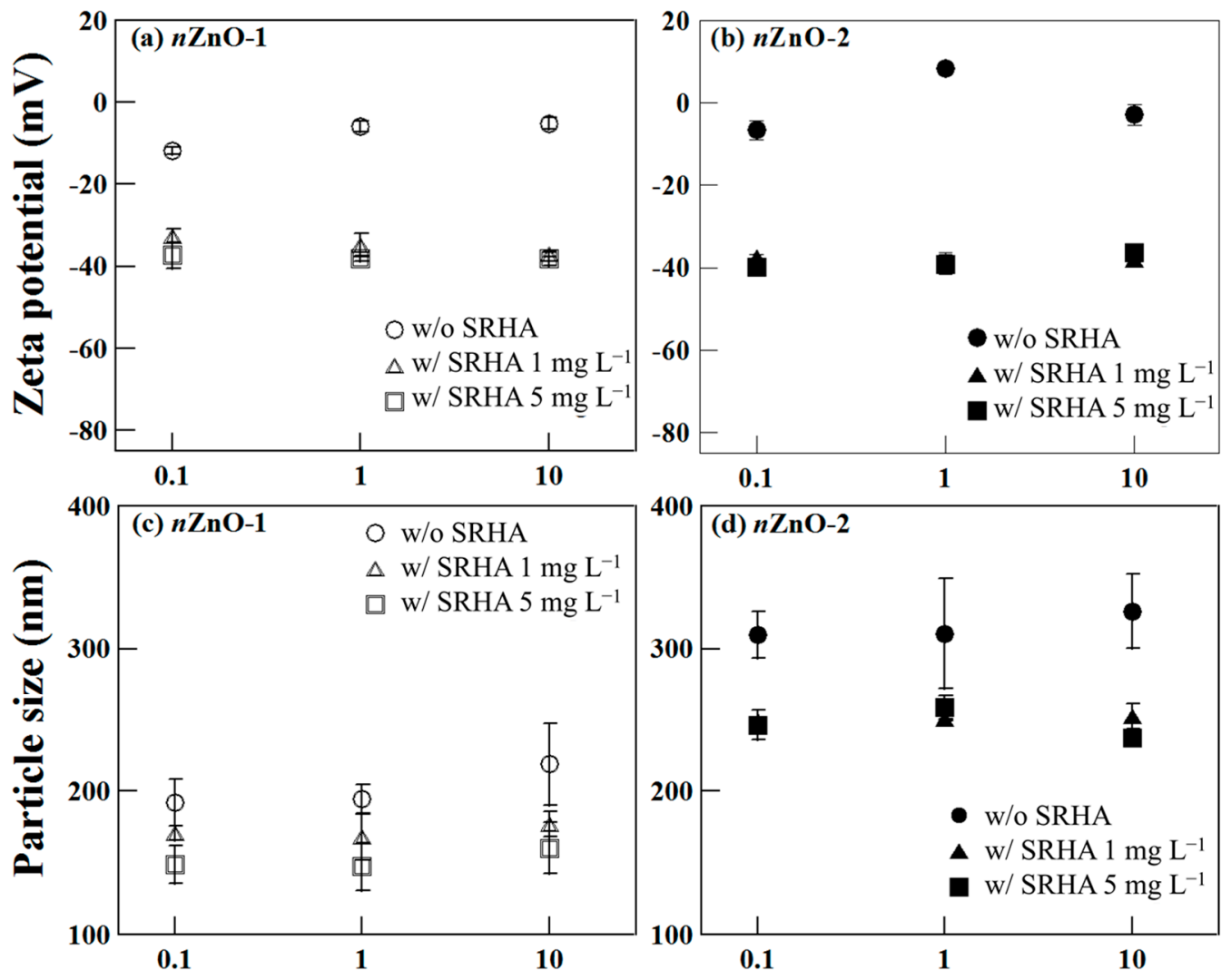

$\mathrm{NaCl}$ concentration $(\mathrm{mM})$

$\mathrm{NaCl}$ concentration $(\mathrm{mM})$

Figure 2. Zeta potentials (a,b) and DLS particle sizes (c,d) of $n \mathrm{ZnO}$ in the absence (w/o SHRA) and presence (w/SRHA) of SRHA at different ionic strengths in both $\mathrm{NaCl}$ solutions at $\mathrm{pH} 9$ (adjusted with $0.1 \mathrm{M} \mathrm{NaOH}$ ).

Table 1. Physical properties of $n \mathrm{ZnO}$ prepared by two different synthesis methods.

\begin{tabular}{|c|c|c|c|c|c|}
\hline \multirow{2}{*}{$\begin{array}{l}\text { Synthesis } \\
\text { Method }\end{array}$} & \multirow{2}{*}{ Sample } & \multicolumn{2}{|c|}{ XRD } & \multirow{2}{*}{$\begin{array}{c}\text { TEM } \\
\text { Primary Particle Size }(\mathrm{nm})^{b}\end{array}$} & \multirow{2}{*}{$\begin{array}{c}\mathrm{N}_{2} \text { Adsorption } \\
\text { Surface Area }\left(\mathrm{m}^{2} \mathrm{~g}^{-1}\right)^{\mathrm{c}}\end{array}$} \\
\hline & & Crystallite Size (nm) ${ }^{a}$ & Crystallite Phase & & \\
\hline 1 & $n \mathrm{ZnO}-1$ & 38.1 & wurtzite & 52.4 & 10.4 \\
\hline 2 & $n \mathrm{ZnO}-2$ & 15.8 & wurtzite & 21.5 & 58.9 \\
\hline
\end{tabular}

${ }^{a}$ Crystallite size calculated according to Scherrer equation from XRD data; ${ }^{\mathrm{b}}$ Primary particle size was determined by averaging more than 400 particles from TEM micrographs; ${ }^{c}$ Specific surface area was measured using BET model based on $\mathrm{N}_{2}$ adsorption of isotherm.

In terms of the two types of $n \mathrm{ZnO}$ size (Figure $2 \mathrm{c}, \mathrm{d}$ ), the $n \mathrm{ZnO}-1$ size in the absence of SRHA ranges from 190 to $220 \mathrm{~nm}$ over the whole ionic strength range, showing little difference as a function of change in ionic strength. This trend is consistent with the DLVO interaction energy calculation between particles, which shows the favorable interaction 
condition even at the lowest ionic strength tested $(0.1 \mathrm{mM})$, and the same is expected at higher ionic strengths; this will be discussed in detail in the Section 3.2. In the presence of SRHA, the size was $\sim 180 \mathrm{~nm}$ or smaller, showing little difference as a function of the change in ionic strength or SRHA concentration. In the absence of SRHA, the $n \mathrm{ZnO}-2$ size ranges from 220 to $330 \mathrm{~nm}$ over the whole ionic strength range, showing little difference as a function of the change in ionic strength. In the presence of SRHA, the size was 260 nm or smaller, showing little difference as a function of the change in ionic strength or SRHA concentration. Eventually, the size of the two types of $n \mathrm{ZnO}$ decreased slightly in the presence of SRHA. The reason was that SRHA further negatively changed the zeta potential of $n \mathrm{ZnO}$ to increase the repulsive electrostatic force among the particles, and to decrease the $n \mathrm{ZnO}$ aggregation level, resulting in a decrease in the $n \mathrm{ZnO}$ size. These outcomes corresponded to those of the zeta potential. In previous studies, SRHA was reported to increase the stability of colloidal particles such as $\mathrm{C}_{60}, \mathrm{TiO}_{2}, \mathrm{NPs}$, hematite, latex, and clay particles [50-55]. The size of $n \mathrm{ZnO}-1$ tended to be smaller than that of $n \mathrm{ZnO}-2$, regardless of the presence/absence of SRHA and the ionic strength.

\subsection{Transport and Retention Behavior of $\mathrm{ZnO}-\mathrm{NPs}$ without SRHA}

To investigate the transport behavior of $n \mathrm{ZnO}$ in the packed column, experiments were conducted in the general soil environment conditions of $\mathrm{NaCl}(0.1-10 \mathrm{mM})$ and at $\mathrm{pH}$ 9. Figure $3 \mathrm{a}, \mathrm{b}$, as well as Figure $4 \mathrm{a}, \mathrm{b}$, show the breakthrough curves and retention profiles of the two types of $n \mathrm{ZnO}$ in the absence of SRHA. In the breakthrough curves of both type of $n \mathrm{ZnO}$ (Figure $3 \mathrm{a}, \mathrm{b}$ ), no breakthrough was observed over the whole ionic strength range (0.1-10 mM). Because no breakthrough was observed with either type of $n \mathrm{ZnO}$, they were considered to have been deposited in the soil media, which corresponded to the results of mass balance (Table S2).

Because no breakthrough was observed with either type of $n \mathrm{ZnO}$ from the column, it was difficult to compare the apparent transport behaviors. Accordingly, the distribution of the $n \mathrm{ZnO}$ retained in quartz sand was investigated by confirming the $n \mathrm{ZnO}$ retention profiles. As described, all the $n \mathrm{ZnO}$ were retained on the column according to the mass balance confirmation (Table S2). According to the retention profiles (Figure 4) of the two types of $n \mathrm{ZnO}$, no difference in the deposition amount was observed as a function of change in ionic strength $(0.1-10 \mathrm{mM})$ between the two types of $n \mathrm{ZnO}$, and the deposition of both type of $n \mathrm{ZnO}$ was confirmed mainly near the column inlet. The similar graph pattern (i.e., large amount of deposition at the column inlet) was also observed from many previous studies $[20,25,56-60]$, and they attributed this trend to the straining caused by the concurrent aggregation among $n \mathrm{ZnO}$. 

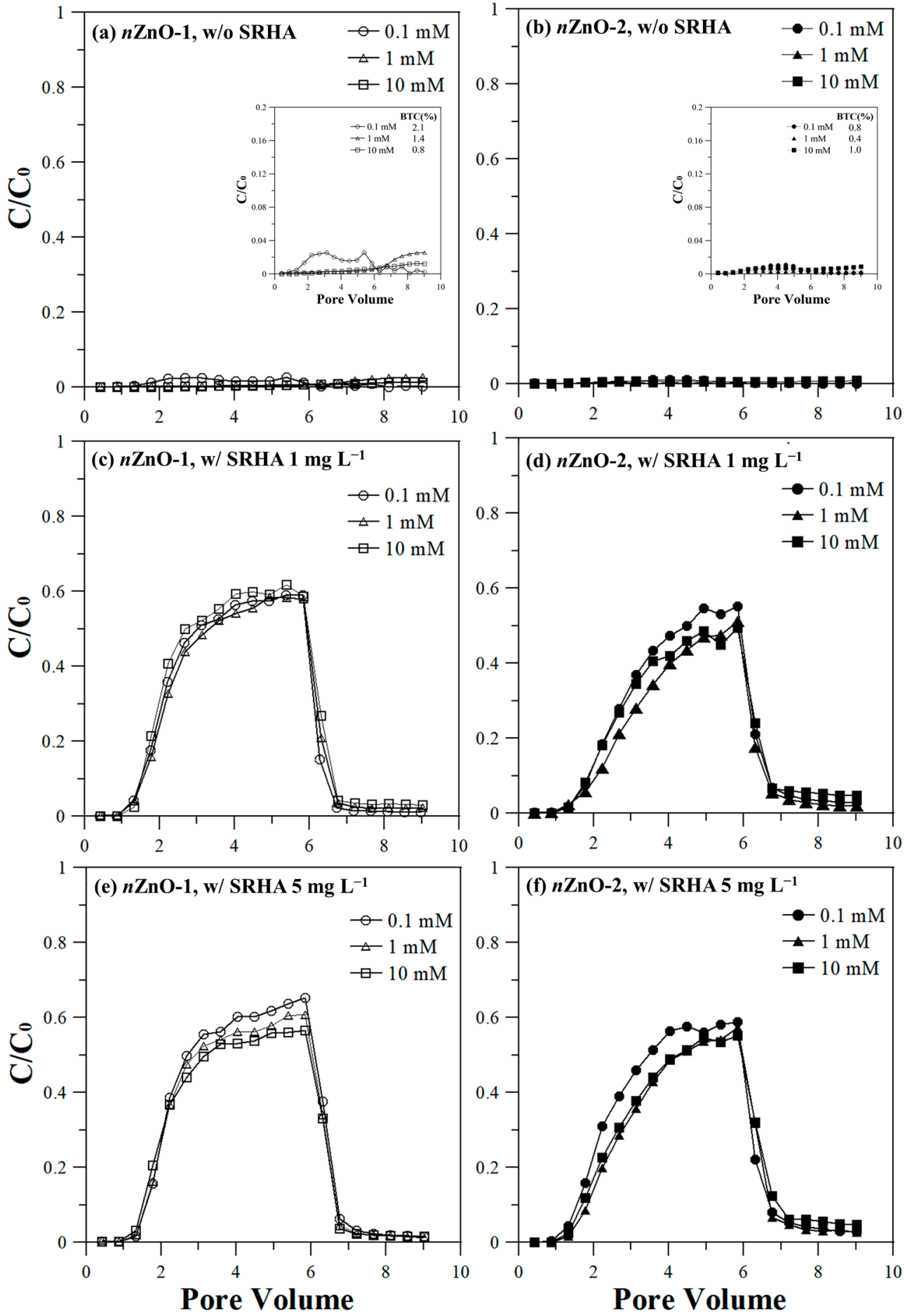

Figure 3. Breakthrough curves of $n \mathrm{ZnO}-1$ (open symbol) and $n \mathrm{ZnO}-2$ (solid symbol) in the absence $(\mathbf{a}, \mathbf{b})$ and presence $(\mathbf{c}-\mathbf{f})$ of suspended SRHA at difference ionic strengths in $\mathrm{NaCl}$ solution $(0.1-10 \mathrm{mM})$. The inset of $(\mathbf{a}, \mathbf{b})$ is the enlarged image of the BTC profiles for clarity; note that the BTC percent is $\leq 2 \%$ for all cases, which is considered negligible. $C / C_{0}$ represents normalized concentration; here, $\mathrm{C}$ and $\mathrm{C}_{0}$ represent the concentration of NPs passing through the column at certain pore volume and of injected NPs suspension, respectively. The pore volume is defined as $\mathrm{t} / \mathrm{VQ}$; here, $\mathrm{t}, \mathrm{V}$, and $\mathrm{Q}$ represent time, column void volume, and volumetric flow rate. 

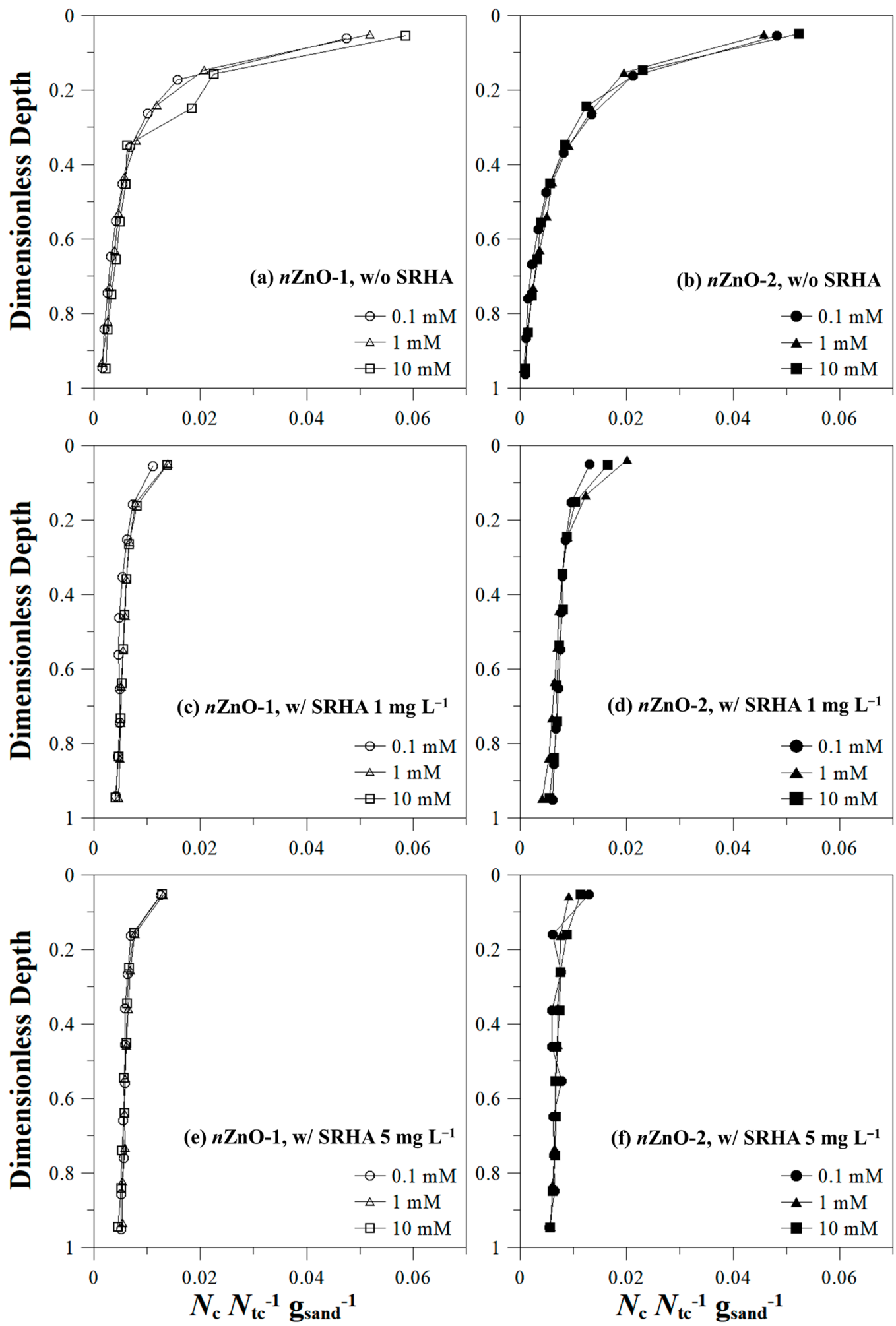

Figure 4. Retention profiles of $n \mathrm{ZnO}-1$ (open symbol) and $n \mathrm{ZnO}-2$ (solid symbol) in the absence $(\mathbf{a}, \mathbf{b})$ and presence $(\mathbf{c}-\mathbf{f})$ of suspended SRHA and at difference ionic strengths in $\mathrm{NaCl}(0.1-10 \mathrm{mM})$. Here, the dimensionless depth represents the normalized column depth (i.e., column depth at certain position divided by total length of the column). The $x$-axis represents the normalized concentration of NPs deposited at a certain depth per unit sand mass; $N_{\mathrm{c}}, N_{\mathrm{tc}}$, and $\mathrm{g}_{\text {sand }}$ represent the number of the deposited NPs, the number of total NPs injected to the column, and the sand weight at a certain depth, respectively. 


\subsection{Transport and Retention Behavior of ZnO-NPs with SRHA}

To compare and analyze the transport behaviors of both types of the $n \mathrm{ZnO}$ in the packed column in the presence of SRHA ( 1 and $\left.5 \mathrm{mg} \mathrm{L}^{-1}\right)$, experiments were conducted using $\mathrm{NaCl}(0.1-10 \mathrm{mM})$ and at $\mathrm{pH}$ 9. The breakthrough curves and retention profiles of both type of $n \mathrm{ZnO}$ affected by SRHA ( 1 and $\left.5 \mathrm{mg} \mathrm{L}^{-1}\right)$ are shown in Figure $3 \mathrm{a}-\mathrm{f}$ as well as Figure $4 \mathrm{c}-\mathrm{f}$, respectively. In the presence of SRHA $\left(1\right.$ and $\left.5 \mathrm{mg} \mathrm{L}^{-1}\right)$, the $n \mathrm{ZnO}-1$ breakthrough curve showed a breakthrough over the whole ionic strength range (0.1-10 $\mathrm{mM})$ unlike the case in the absence of SRHA, but no difference in the breakthrough amount was observed as a function of ionic strength or SRHA concentration ( 1 and $5 \mathrm{mg} \mathrm{L}^{-1}$ ). Similar to $n \mathrm{ZnO}-1, n \mathrm{ZnO}-2$ showed a breakthrough with the presence of SRHA ( 1 and $\left.5 \mathrm{mg} \mathrm{L}^{-1}\right)$, but there was no difference in the breakthrough amount as a function of change in ionic strength $(0.1-10 \mathrm{mM})$ or SRHA concentration $\left(1\right.$ and $\left.5 \mathrm{mg} \mathrm{L}^{-1}\right)$. The patterns of both types of $n \mathrm{ZnO}$ breakthrough curves were flat breakthrough plateaus or non-ripening blocks. To further investigate the transport behavior of both types of $n \mathrm{ZnO}$, the profiles of $n \mathrm{ZnO}$ retained in the column were analyzed. Unlike the case in the absence of SRHA, no large amount of deposition at the column inlet was observed in the presence of SRHA ( 1 and $5 \mathrm{mg} \mathrm{L}^{-1}$ ) as a function of the change in the $n \mathrm{ZnO}-1$ ionic strength $(0.1-10 \mathrm{mM}$ ). No difference in retained $n \mathrm{ZnO}$ was observed as a function of change in ionic strength (0.1-10 mM), and no difference as a function of the change in SRHA (1 and $\left.5 \mathrm{mg} \mathrm{L}^{-1}\right)$ was seen either. In the presence of SRHA $\left(1\right.$ and $\left.5 \mathrm{mg} \mathrm{L}^{-1}\right)$, the retention profiles of $n \mathrm{ZnO}-2$ and $n \mathrm{ZnO}-1$ showed no difference in retained $n \mathrm{ZnO}$ regardless of the change in ionic strength $(0.1-10 \mathrm{mM})$, and no difference as a function of the change in SRHA (1 and $\left.5 \mathrm{mg} \mathrm{L}^{-1}\right)$ was seen either. The reasons for the increase in the transport of both types of $n \mathrm{ZnO}$ in the presence of SRHA ( 1 and $5 \mathrm{mg} \mathrm{L}^{-1}$ ) include first that the suspended SRHA is adsorbed into the surface of $n \mathrm{ZnO}$, resulting in the $n \mathrm{ZnO}$ zeta potential being more negative, and eventually, the repulsive electrostatic force between $n \mathrm{ZnO}$ and the sand surface increases. Second, there is deposition site competition between NPs and suspended SRHA. These two reasons were verified as follows.

To verify the first point, DLVO interaction energy profiles were calculated; the results are shown in Figure 5a. Because the difference in transport as a function of the change in the ionic strength and SRHA content was not significant between the two types of $n \mathrm{ZnO}$, the results of representative conditions, such as $0.1 \mathrm{mM}$ ionic strength and $5 \mathrm{mg} \mathrm{L}^{-1}$ SRHA, are shown. The interaction energy profiles for other conditions $\left(1 \mathrm{mg} \mathrm{L}^{-1}\right.$ SRHA in 1 and $10 \mathrm{mM} \mathrm{NaCl}$ ) can also be found in the Supplementary Information (Figures S4 and S5). In Figure 5a, the energy barrier was observed in all conditions; the level was significantly low in the absence of SRHA, whereas the level was higher in the presence of $5 \mathrm{mg} \mathrm{L}^{-1}$ SRHA. In the absence of SRHA, the NPs-sand energy barrier was low, NPs could probably overcome the energy barrier, all the $n \mathrm{ZnO}$ were deposited on the column, and consequently, no breakthrough occurred. In the presence of $5 \mathrm{mg} \mathrm{L}^{-1}$ SRHA, the NPs-sand energy barrier level was significantly higher, so $n \mathrm{ZnO}$ could not deposit on the sand, due to the stronger repulsive force, and consequently, breakthrough occurred [19,21]. 


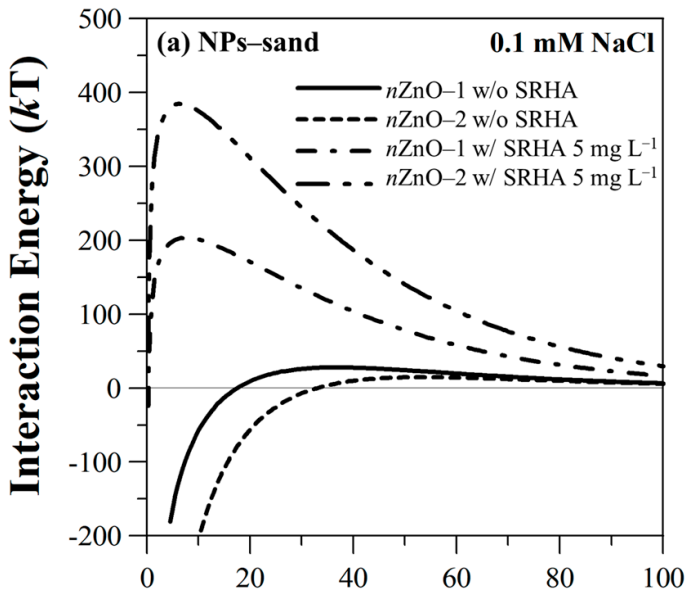

Separation Distance (nm)

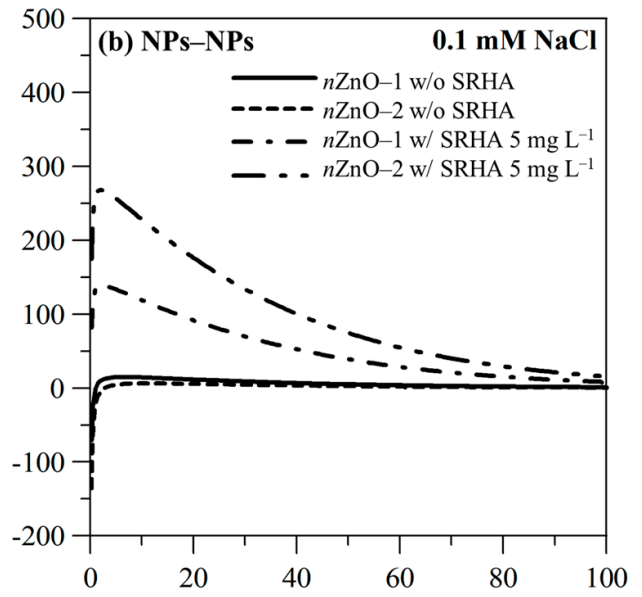

Separation Distance (nm)

Figure 5. DLVO interaction forces of two types of $n \mathrm{ZnO}$ for quartz sand surfaces-nanoparticle (a) and nanoparticle-nanoparticle (b) and in $\mathrm{NaCl}$ solution $(0.1 \mathrm{mM})$.

To verify the second point, SRHA was coated on the sand for the column test. If deposition site competition was the main mechanism, the column packed with SRHAcoated sand might show improved $n \mathrm{ZnO}$ transport versus the column packed with bare sand. $\mathrm{NaCl}$ with a desired ionic strength was supplied to the column packed with sand to reach equilibrium; then, $5 \mathrm{mg} \mathrm{L}^{-1}$ SRHA was supplied in as much as $5 \mathrm{PV}$ to coat the quartz sand. To remove the SRHA remaining in the column pores, $\mathrm{NaCl}$ with the same ionic strength was supplied at $2 \mathrm{PV}$. All the tests were conducted at $\mathrm{pH} 9$ and two levels of ionic strength $(0.1$ and $10 \mathrm{mM} \mathrm{NaCl})$. The transport and retention behaviors of both type of $n \mathrm{ZnO}$ with the presence/absence of suspended SRHA $\left(5 \mathrm{mg} \mathrm{L}^{-1}\right)$ are shown in Figure 6 . In the absence of suspended SRHA, $n \mathrm{ZnO}-1$ showed breakthrough with SRHA-coated quartz sand, and the breakthrough amount decreased with the increase in ionic strength $(0.1$ and $10 \mathrm{mM})$. The reason was that with the increase in ionic strength, the electrostatic repulsive force between NPs and SHRA-coated sand decreased, and more and more NPs were deposited, resulting in a low level of breakthrough. This corresponded to the results of previous studies that confirmed an increase in the deposition of various nanoparticles $\left(\mathrm{C}_{60}, \mathrm{TiO}_{2}\right.$, and $\left.\mathrm{Fe}^{0}\right)$ with decreasing ionic strength $[25,61,62]$. The $n \mathrm{ZnO}-1$ breakthrough curves showed a ripening pattern due to the aggregation among NPs in the porous media. However, $n \mathrm{ZnO}-2$ showed no breakthrough at any ionic strength regardless of the SRHA coating. The reason for the difference in the transport behavior between the two NPs was due mainly to the difference in the zeta potential between $n \mathrm{ZnO}-1$ and $n \mathrm{ZnO}-2$. In the presence of suspended SRHA, no difference in the breakthrough amount of $n \mathrm{ZnO}-1$ was observed regardless of sand coating or ionic strength. In $n \mathrm{ZnO}-2$, no difference in the breakthrough amount was observed regardless of sand coating or change in the ionic strength either. The reason for the lack of difference regardless of SRHA coating was that the $5 \mathrm{mg} \mathrm{L}^{-1}$ suspended SRHA could be sufficiently adsorbed into the heterogeneous sites that were present in sand in a patch form. Based on these results, deposition site competition between $n \mathrm{ZnO}$ and suspended SRHA was confirmed as the main retention mechanism of $n \mathrm{ZnO}$. In addition, because the rate of SRHA depositing to sand was higher than that of $n \mathrm{ZnO}$, the $n \mathrm{ZnO}$ transport improved in the presence of suspended SRHA. 

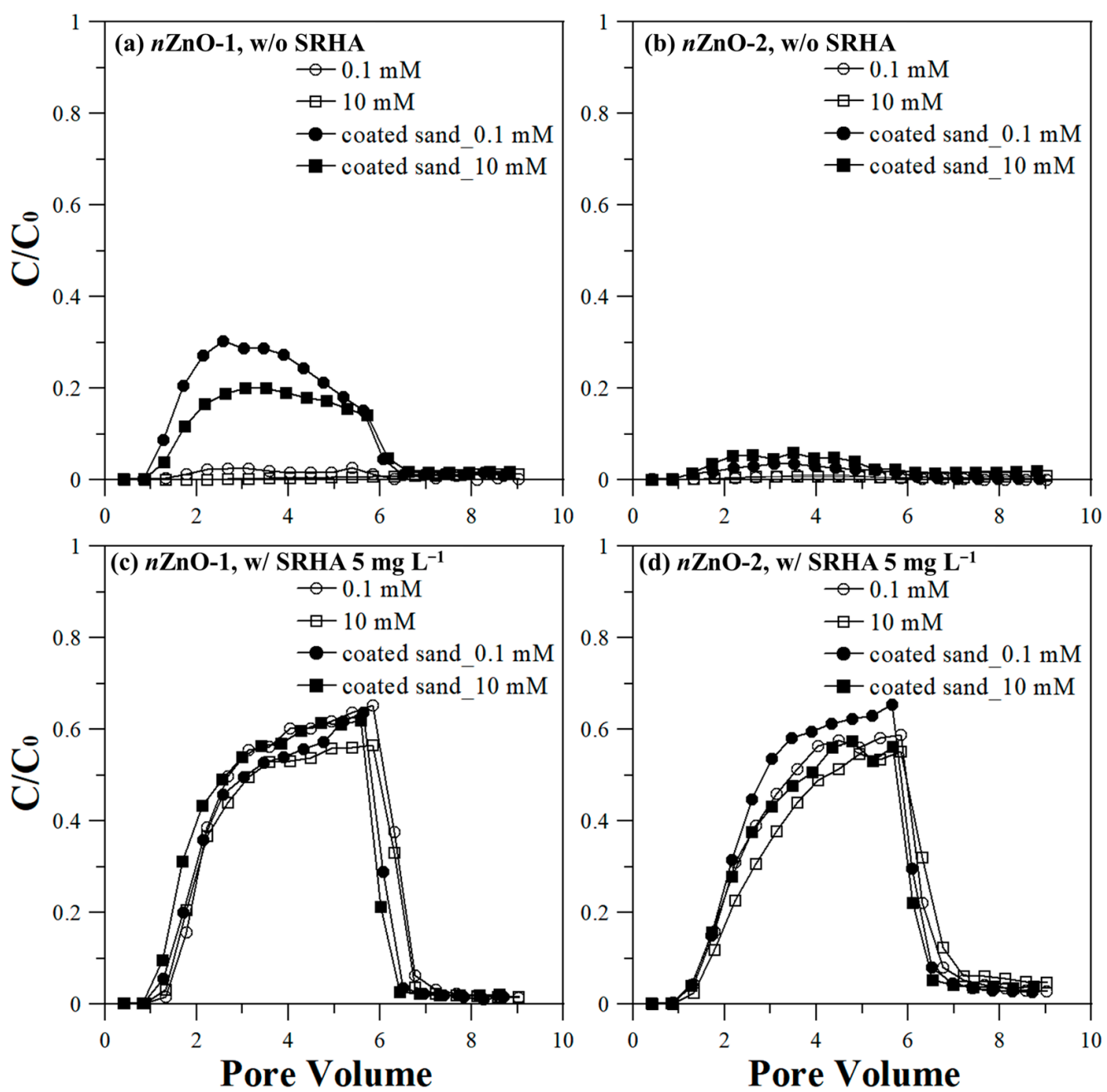

Figure 6. Breakthrough curves of $n \mathrm{ZnO}-1$ and $n \mathrm{ZnO}-2$ in the absence $(\mathbf{a}, \mathbf{b})$ and presence $(\mathbf{c}, \mathbf{d})$ of suspended SRHA ( $5 \mathrm{mg} \mathrm{L}^{-1}$ ) and in the presence (solid symbol) and absence (open symbol) of coated SRHA at difference ionic strengths in $\mathrm{NaCl}$ solution $(0.1$ and $10 \mathrm{mM})$.

In the absence of SRHA, the $n \mathrm{ZnO}$ was largely retained in the column inlet. To investigate the reason, the NPs-NPs DLVO interaction energy profiles were calculated, and the results are shown in Figure 5b. As a result of confirming the NPs-NPs interaction energy profiles, an active NP aggregation developed because the significantly low energy barrier in the absence of SHRA was overcome by $n \mathrm{ZnO}$ Brownian motion or collision force [63]. The massive $n \mathrm{ZnO}$ deposition in the column inlet area could be explained by $\mathrm{NP}$ aggregation. In the presence of SRHA, a high level of energy barrier was confirmed due to the NPs-NPs interaction energy (unfavorable conditions). The significantly strong repulsive force reduced NPs aggregation, resulting in no mass deposition in the column inlet area.

While no difference in breakthrough curves and retention profiles was observed between the two types of $n \mathrm{ZnO}$ according to the change in ionic strength in the absence of SRHA, differences in the transport behavior were observed between $n \mathrm{ZnO}-1$ and $n \mathrm{ZnO}-2$ in the presence of $1 \mathrm{mg} \mathrm{L}^{-1}$ SRHA (Figure 7a,b). More specifically, the $n \mathrm{ZnO}-1$ breakthrough amount was confirmed at $47-52 \%$, and $n \mathrm{ZnO}-2,34-40 \%$. In the presence of $5 \mathrm{mg} \mathrm{L}^{-1}$ SRHA, the breakthrough amount of $n \mathrm{ZnO}-1$ was $48-53 \%$, and that of $n \mathrm{ZnO}-2,41-48 \%$. The transportability of $n \mathrm{ZnO}-1$ was confirmed to be higher than that of $n \mathrm{ZnO}-2$. To explain the difference in the transport of the two types of $n \mathrm{ZnO}$, the zeta potential of $n \mathrm{ZnO}$ was investigated. No difference in the zeta potential was observed between the two types of $n \mathrm{ZnO}$ according to the SRHA concentration and ionic strength in the presence of SRHA (1 
and $5 \mathrm{mg} \mathrm{L}^{-1}$ ). As described, the zeta potential was not sufficient to explain the difference in the transport, so the NPs-sand DLVO interaction energy profiles were calculated to compare the NPs. As a result, the energy barrier of $n \mathrm{ZnO}-1$ was confirmed to be $\sim 200 \mathrm{kT}$, and that of $n \mathrm{ZnO}-2, \sim 400 \mathrm{kT}$. The NPs-sand DLVO interaction energy profiles were not enough to explain the difference because the energy barrier of both particles was quite high, and $n \mathrm{ZnO}-2$ showed a higher energy barrier but lower transportability than $n \mathrm{ZnO}-1$. Finally, the main mechanism of NP transport was confirmed in Section 3.3 to be deposition site competition between suspended SRHA and NPs in the presence of SRHA, so the amount of adsorption to each $n \mathrm{ZnO}$, according to the SRHA concentration level, was confirmed, and the results are shown in Figure $7 \mathrm{c}$. $n \mathrm{ZnO}-1$ showed less adsorption of SRHA than $n \mathrm{ZnO}-2$ regardless of the SRHA concentration. This indicates that the amount of remaining SRHA (i.e., suspended SRHA) was larger than that adsorbed in the $n \mathrm{ZnO}-1$ suspension. Accordingly, in the case of $n \mathrm{ZnO}-1$, which had more suspended SRHA, more deposition sites on the sand surface were occupied by SRHA, and, consequently, the number of NPs deposition sites decreased to improve transport. These phenomena were supported by the absence of a difference in the adsorption amount between $n \mathrm{ZnO}-1$ and $n \mathrm{ZnO}-2$ regardless of the change in ionic strength, and by the lack of difference in transport. In previous studies, more suspended SRHA amount was confirmed to have resulted in more $\mathrm{TiO}_{2}$ transport amount $[25,64]$.
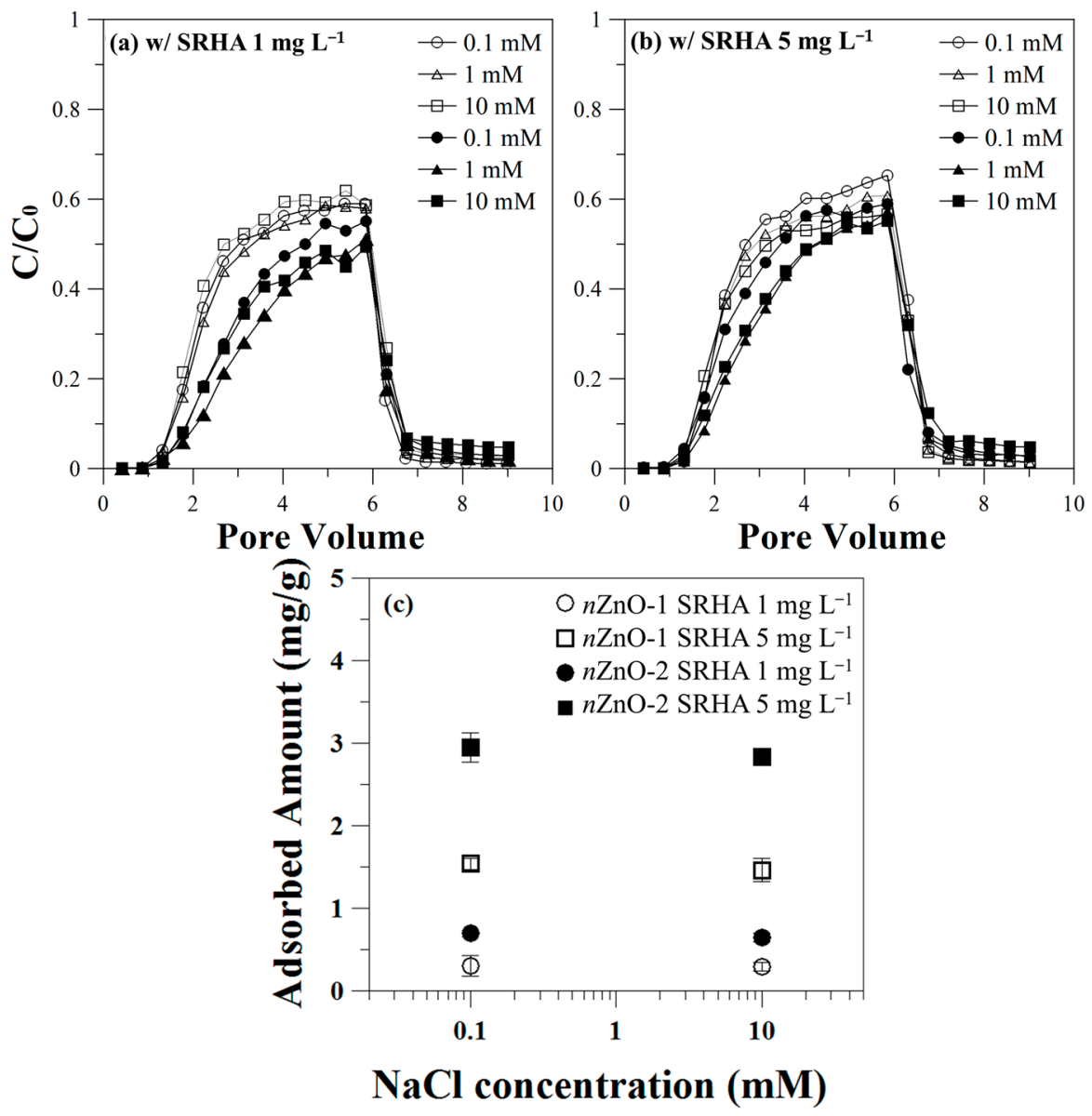

Figure 7. Breakthrough curves of $n \mathrm{ZnO}-1$ (open symbol) and $n \mathrm{ZnO}-2$ (solid symbol) in the presence of SRHA ( 1 and $5 \mathrm{mg} \mathrm{L}^{-1}$ for $(\mathbf{a}, \mathbf{b})$, respectively) at difference ionic strengths in $\mathrm{NaCl}$ solution (0.1-10 mM). (c) shows the amount of SRHA adsorbed on the $n \mathrm{ZnO}-1$ (open symbol) and $n \mathrm{ZnO}-2$ (solid symbol) surface as a function of solution ionic strength in the presence of an initial SRHA concentration of 1 and $5 \mathrm{mg} \mathrm{L}^{-1}$ at $\mathrm{pH} 9$. 


\section{Conclusions}

Regarding the transport and retention behavior of $n \mathrm{ZnO}$, no breakthrough was observed in either type in the absence of suspended SRHA. The NPs-NPs concurrent aggregation resulted in a massive deposition of $n \mathrm{ZnO}$ on the column inlet. In the presence of suspended SHRA, however, no massive deposition was observed. Specifically, 47.0-53.2\% of injected $n \mathrm{ZnO}-1$ passed through the column, while $33.4-47.5 \%$ passed through for $n \mathrm{ZnO}-2$. These outcomes were based on the increase in the $n \mathrm{ZnO}$ transport that was facilitated by the increase in the electrostatic repulsive force among $n \mathrm{ZnO}$, which was caused by the SHRA adsorbed into the $n \mathrm{ZnO}$ surface.

The transportability of $n \mathrm{ZnO}-1$ was observed to be higher than that of $n \mathrm{ZnO}-2$, and in the absence of SRHA in the coated soil column, breakthrough was observed only with $n \mathrm{ZnO}-1$ (17.2-23.8\%). To further investigate the $n \mathrm{ZnO}$ transport behavior, tests determining the amount of SRHA adsorbed to $n \mathrm{ZnO}$ were conducted. As a result, $n \mathrm{ZnO}-1$ showed less SRHA adsorption than $n \mathrm{ZnO}-2$ regardless of ionic strength. Eventually, with more remaining SHRA not adsorbed to $n \mathrm{ZnO}$, more $n \mathrm{ZnO}$ transport was confirmed in the study. Based on the results above, deposition site competition between $n \mathrm{ZnO}$ and suspended SHRA was confirmed as the major retention mechanism of $n \mathrm{ZnO}$ transport. Furthermore, $n \mathrm{ZnO}$ transport increased in the presence of abundant suspended SRHA because the deposition rate of SRHA to soil media was higher than that of $n \mathrm{ZnO}$.

Supplementary Materials: The following are available online at https://www.mdpi.com/article/ 10.3390/app11198957/s1, Additional Details on Materials and Methods, Additional Results and Discussion, Figure S1: TGA profiles for the prepared two types of $n \mathrm{ZnO}$ by difference synthesis conditions, Figure S2: ATR-FTIR spectra of two types of $n \mathrm{ZnO}$ obtained from synthesis conditions, Figure S3: Specific surface areas of two types of $n \mathrm{ZnO}$ from Brunauer-Emmet-Teller (BET) method, Figure S4: DLVO interaction energy profiles of $n \mathrm{ZnO}-1$ for NPs-NPs (solid line) and NPs-sand (dashed line) surfaces in $\mathrm{NaCl}(1-10 \mathrm{mM})$ solutions in the absence/presence SRHA, Figure S5: DLVO interaction energy profiles of $n \mathrm{ZnO}-2$ for NPs-NPs (solid line) and NPs-sand (dashed line) surfaces in $\mathrm{NaCl}(1-10 \mathrm{mM})$ solutions in the absence/presence SRHA, Table S1: Parameters used to calculate DLVO interaction energy profiles, Table S2: Mass balance for two types of $n \mathrm{ZnO}$ in column experiments.

Author Contributions: Writing—original draft preparation, methodology, investigation: D.K.; conceptualization, writing —original draft preparation, formal analysis, review and editing: G.H. All authors have read and agreed to the published version of the manuscript.

Funding: This research received no external funding.

Acknowledgments: This work was supported by the National Institute of Environmental Research, Ministry of the Environment.

Conflicts of Interest: The authors declare that there are no potential conflicts of interest with respect to the research, authorship, and/or publication of this article.

\section{References}

1. Klaine, S.J.; Alvarez, P.; Batley, G.E.; Fernandes, T.; Handy, R.D.; Lyon, D.; Mahendra, S.; McLaughlin, M.J.; Lead, J.R. Nanomaterials in the environment: Behavior, fate, bioavailability, and effects. Environ. Toxicol. Chem. 2008, 27, 1825-1851. [CrossRef]

2. $\mathrm{Xu}, \mathrm{N}$.; Cheng, X.; Wang, D.; Xu, X.; Huangfu, X.; Li, Z. Effects of Escherichia coli and phosphate on the transport of titanium dioxide nanoparticles in heterogeneous porous media. Water Res. 2018, 146, 264-274. [CrossRef]

3. Nikolova, M.P.; Chavali, M.S. Metal Oxide Nanoparticles as Biomedical Materials. Biomimetics 2020, 5, 27. [CrossRef]

4. Han, Y.; Hwang, G.; Kim, D.; Bradford, S.A.; Lee, B.; Eom, I.; Kim, P.J; Choi, S.; Kim, H. Transport, retention, and long-term release behavior of $\mathrm{ZnO}$ nanoparticle aggregates in saturated quartz sand: Role of solution $\mathrm{pH}$ and biofilm coating. Water Res. 2016, 90, 247-257. [CrossRef]

5. Mu, L.; Sprando, R.L. Application of Nanotechnology in Cosmetics. Pharm. Res. 2010, 27, 1746-1749. [CrossRef]

6. Wang, Z.L.; Song, J. Piezoelectric nanogenerators based on zinc oxide nanowire arrays. Science 2006, 312, 242-246. [CrossRef]

7. Sari, M.G.; Vahabi, H.; Gabrion, X.; Laheurte, P.; Zarintaj, P.; Formela, K.; Saeb, M.R. An attempt to mechanistically explain the viscoelastic behavior of transparent epoxy/starch-modified $\mathrm{ZnO}$ nanocomposite coatings. Prog. Org. Coat. 2018, 119, 171-182. [CrossRef] 
8. Adams, L.K.; Lyon, D.Y.; Alvarez, P.J. Comparative eco-toxicity of nanoscale $\mathrm{TiO}_{2}, \mathrm{SiO}_{2}$, and $\mathrm{ZnO}$ water suspensions. Water Res. 2006, 40, 3527-3532. [CrossRef] [PubMed]

9. Gopalan, R.; Osman, I.F.; Amani, A.; De Matas, M.; Anderson, D. The effect of zinc oxide and titanium dioxide nanoparticles in the Comet assay with UVA photoactivation of human sperm and lymphocytes. Nanotoxicology 2009, 3, 33-39. [CrossRef]

10. Lin, D.; Xing, B. Phytotoxicity of nanoparticles: Inhibition of seed germination and root growth. Environ. Pollut. 2007, 150, 243-250. [CrossRef]

11. Lin, D.; Xing, B. Root Uptake and Phytotoxicity of ZnO Nanoparticles. Environ. Sci. Technol. 2008, 42, 5580-5585. [CrossRef]

12. Osman, I.F.; Baumgartner, A.; Cemeli, E.; Fletcher, J.N.; Anderson, D. Genotoxicity and cytotoxicity of zinc oxide and titanium dioxide in HEp-2 cells. Nanomedicine 2010, 5, 1193-1203. [CrossRef]

13. Simon-Deckers, A.; Loo, S.; Mayne-L'hermite, M.; Herlin-Boime, N.; Menguy, N.; Reynaud, C.; Gouget, B.; Carriere, M. Size-, composition-and shape-dependent toxicological impact of metal oxide nanoparticles and carbon nanotubes toward bacteria. Environ. Sci. Technol. 2009, 43, 8423-8429. [CrossRef] [PubMed]

14. Xia, T.; Kovochich, M.; Liong, M.; Mädler, L.; Gilbert, B.; Shi, H.; Yeh, J.I.; Zink, J.I.; Nel, A.E. Comparison of the Mechanism of Toxicity of Zinc Oxide and Cerium Oxide Nanoparticles Based on Dissolution and Oxidative Stress Properties. ACS Nano 2008, 2, 2121-2134. [CrossRef] [PubMed]

15. Lee, B.; Hong, G.; Lee, H.; Kim, P.; Seo, D.-Y.; Hwang, G.; Kim, G.; Kim, P. Influence of NOM on the stability of zinc oxide nanoparticles in ecotoxicity tests. Appl. Sci. 2020, 10, 6431. [CrossRef]

16. Zhang, L.; Jiang, Y.; Ding, Y.; Povey, M.; York, D.W. Investigation into the antibacterial behaviour of suspensions of ZnO nanoparticles (ZnO nanofluids). J. Nanopart. Res. 2007, 9, 479-489. [CrossRef]

17. Xia, T.; Zhao, Y.; Sager, T.; George, S.; Pokhrel, S.; Li, N.; Schoenfeld, D.; Meng, H.; Lin, S.; Wang, X.; et al. Decreased Dissolution of ZnO by Iron Doping Yields Nanoparticles with Reduced Toxicity in the Rodent Lung and Zebrafish Embryos. ACS Nano 2011, 5, 1223-1235. [CrossRef] [PubMed]

18. Ben-Moshe, T.; Dror, I.; Berkowitz, B. Transport of metal oxide nanoparticles in saturated porous media. Chemosphere 2010, 81, 387-393. [CrossRef] [PubMed]

19. Jiang, X.; Tong, M.; Kim, H. Influence of natural organic matter on the transport and deposition of zinc oxide nanoparticles in saturated porous media. J. Colloid Interface Sci. 2012, 386, 34-43. [CrossRef] [PubMed]

20. Jiang, X.; Tong, M.; Lu, R.; Kim, H. Transport and deposition of ZnO nanoparticles in saturated porous media. Colloids Surf. A Physicochem. Eng. Asp. 2012, 401, 29-37. [CrossRef]

21. Jones, E.H.; Su, C. Transport and retention of zinc oxide nanoparticles in porous media: Effects of natural organic matter versus natural organic ligands at circumneutral pH. J. Hazard. Mater. 2014, 275, 79-88. [CrossRef]

22. Kanel, S.; Al-Abed, S.R. Influence of $\mathrm{pH}$ on the transport of nanoscale zinc oxide in saturated porous media. J. Nanopart. Res. 2011, 13, 4035-4047. [CrossRef]

23. Kurlanda-Witek, H.; Ngwenya, B.; Butler, I. Transport of bare and capped zinc oxide nanoparticles is dependent on porous medium composition. J. Contam. Hydrol. 2014, 162, 17-26. [CrossRef]

24. Petosa, A.R.; Brennan, S.J.; Rajput, F.; Tufenkji, N. Transport of two metal oxide nanoparticles in saturated granular porous media: Role of water chemistry and particle coating. Water Res. 2012, 46, 1273-1285. [CrossRef]

25. Han, P.; Wang, X.; Cai, L.; Tong, M.; Kim, H. Transport and retention behaviors of titanium dioxide nanoparticles in iron oxide-coated quartz sand: Effects of $\mathrm{pH}$, ionic strength, and humic acid. Colloids Surf. A Physicochem. Eng. Asp. 2014, 454, 119-127. [CrossRef]

26. Becheri, A.; Dürr, M.; Nostro, P.L.; Baglioni, P. Synthesis and characterization of zinc oxide nanoparticles: Application to textiles as UV-absorbers. J. Nanopart. Res. 2008, 10, 679-689. [CrossRef]

27. Wang, L.; Muhammed, M. Synthesis of zinc oxide nanoparticles with controlled morphology. J. Mater. Chem. 1999, 9, 2871-2878. [CrossRef]

28. Han, Y.; Kim, D.; Hwang, G.; Lee, B.; Eom, I.; Kim, P.J.; Tong, M.; Kim, H. Aggregation and dissolution of ZnO nanoparticles synthesized by different methods: Influence of ionic strength and humic acid. Colloids Surf. A Physicochem. Eng. Asp. 2014, 451, 7-15. [CrossRef]

29. Lim, M.; Hwang, G.; Bae, S.; Jang, M.-H.; Choi, S.; Kim, H.; Hwang, Y.S. Transport of citrate-coated silver nanoparticles in saturated porous media. Environ. Geochem. Health 2019, 42, 1753-1766. [CrossRef]

30. Peng, S.; Wu, D.; Ge, Z.; Tong, M.; Kim, H. Influence of graphene oxide on the transport and deposition behaviors of colloids in saturated porous media. Environ. Pollut. 2017, 225, 141-149. [CrossRef] [PubMed]

31. Noman, M.T.; Amor, N.; Petru, M. Synthesis and applications of ZnO nanostructures (ZONSs): A review. Crit. Rev. Solid State Mater. Sci. 2021, 1-43. [CrossRef]

32. Wojnarowicz, J.; Chudoba, T.; Lojkowski, W. A Review of Microwave Synthesis of Zinc Oxide Nanomaterials: Reactants, Process Parameters and Morphologies. Nanomaterials 2020, 10, 1086. [CrossRef] [PubMed]

33. Bandeira, M.; Giovanela, M.; Roesch-Ely, M.; Devine, D.M.; Crespo, J.D.S. Green synthesis of zinc oxide nanoparticles: A review of the synthesis methodology and mechanism of formation. Sustain. Chem. Pharm. 2020, 15, 100223. [CrossRef]

34. Han, Y.; Choi, J.; Tong, M.; Kim, H. Synthesis and characterization of high-surface-area millimeter-sized silica beads with hierarchical multi-modal pore structure by the addition of agar. Mater. Charact. 2014, 90, 31-39. [CrossRef] 
35. Han, Y.; Kim, H.; Park, J.; Lee, S.-H.; Kim, J.-Y. Influence of Ti doping level on hydrogen adsorption of mesoporous Ti-SBA-15 materials prepared by direct synthesis. Int. J. Hydrogen Energy 2012, 37, 14240-14247. [CrossRef]

36. Hwang, G.; Gomez-Flores, A.; Bradford, S.A.; Choi, S.; Jo, E.; Kim, S.B.; Tong, M.; Kim, H. Analysis of stability behavior of carbon black nanoparticles in ecotoxicological media: Hydrophobic and steric effects. Colloids Surf. A Physicochem. Eng. Asp. 2018, 554, 306-316. [CrossRef]

37. Han, Y.; Hwang, G.; Park, S.; Flores, A.G.; Jo, E.; Eom, I.-C.; Tong, M.; Kim, H.-J.; Kim, H. Stability of carboxyl-functionalized carbon black nanoparticles: The role of solution chemistry and humic acid. Environ. Sci. Nano 2017, 4, 800-810. [CrossRef]

38. Kim, H.; Walker, S.L.; Bradford, S.A. Coupled factors influencing the transport and retention of Cryptosporidium parvum oocysts in saturated porous media. Water Res. 2010, 44, 1213-1223. [CrossRef]

39. Kim, H.; Walker, S.L.; Bradford, S.A. Macromolecule mediated transport and retention of Escherichia coli O157:H7 in saturated porous media. Water Res. 2010, 44, 1082-1093. [CrossRef]

40. Gregory, J. Approximate expressions for retarded van der waals interaction. J. Colloid Interface Sci. 1981, 83, 138-145. [CrossRef]

41. Bergström, L. Hamaker constants of inorganic materials. Adv. Colloid Interface Sci. 1997, 70, 125-169. [CrossRef]

42. Hu, J.-D.; Zevi, Y.; Kou, X.-M.; Xiao, J.; Wang, X.-J.; Jin, Y. Effect of dissolved organic matter on the stability of magnetite nanoparticles under different $\mathrm{pH}$ and ionic strength conditions. Sci. Total Environ. 2010, 408, 3477-3489. [CrossRef] [PubMed]

43. Israelachvili, J.N. Intermolecular and Surface Forces; Academic Press: Cambridge, MA, USA, 2015.

44. Hogg, R.; Healy, T.W.; Fuerstenau, D.W. Mutual coagulation of colloidal dispersions. Trans. Faraday Soc. 1966, 62, $1638-1651$. [CrossRef]

45. Gregory, J. Particles in Water: Properties and Processes; CRC Press: Boca Raton, FL, USA, 2005.

46. Bian, S.-W.; Mudunkotuwa, I.A.; Rupasinghe, T.; Grassian, V.H. Aggregation and Dissolution of $4 \mathrm{~nm} Z \mathrm{ZnO}$ Nanoparticles in Aqueous Environments: Influence of pH, Ionic Strength, Size, and Adsorption of Humic Acid. Langmuir 2011, 27, 6059-6068. [CrossRef]

47. Keller, A.A.; Wang, H.; Zhou, D.; Lenihan, H.S.; Cherr, G.; Cardinale, B.J.; Miller, R.; Ji, Z. Stability and Aggregation of Metal Oxide Nanoparticles in Natural Aqueous Matrices. Environ. Sci. Technol. 2010, 44, 1962-1967. [CrossRef] [PubMed]

48. Yang, K.; Lin, D.; Xing, B. Interactions of Humic Acid with Nanosized Inorganic Oxides. Langmuir 2009, 25, 3571-3576. [CrossRef] [PubMed]

49. Zhang, Y.; Chen, Y.; Westerhoff, P.; Crittenden, J. Impact of natural organic matter and divalent cations on the stability of aqueous nanoparticles. Water Res. 2009, 43, 4249-4257. [CrossRef] [PubMed]

50. Chen, K.L.; Elimelech, M. Influence of humic acid on the aggregation kinetics of fullerene $\left(\mathrm{C}_{60}\right)$ nanoparticles in monovalent and divalent electrolyte solutions. J. Colloid Interface Sci. 2007, 309, 126-134. [CrossRef]

51. Deshiikan, S.R.; Eschenazi, E.; Papadopoulos, K.D. Transport of colloids through porous beds in the presence of natural organic matter. Colloids Surf. A Physicochem. Eng. Asp. 1998, 145, 93-100. [CrossRef]

52. Heidmann, I.; Christl, I.; Kretzschmar, R. Aggregation Kinetics of Kaolinite-Fulvic Acid Colloids as Affected by the Sorption of $\mathrm{Cu}$ and $\mathrm{Pb}$. Environ. Sci. Technol. 2005, 39, 807-813. [CrossRef]

53. Illés, E.; Tombácz, E. The effect of humic acid adsorption on pH-dependent surface charging and aggregation of magnetite nanoparticles. J. Colloid Interface Sci. 2006, 295, 115-123. [CrossRef] [PubMed]

54. Mylon, S.E.; Chen, K.L.; Elimelech, M. Influence of Natural Organic Matter and Ionic Composition on the Kinetics and Structure of Hematite Colloid Aggregation: Implications to Iron Depletion in Estuaries. Langmuir 2004, 20, 9000-9006. [CrossRef] [PubMed]

55. Thio, B.J.R.; Zhou, D.; Keller, A.A. Influence of natural organic matter on the aggregation and deposition of titanium dioxide nanoparticles. J. Hazard. Mater. 2011, 189, 556-563. [CrossRef] [PubMed]

56. Bradford, S.A.; Simunek, J.; Walker, S.L. Transport and straining of E. coli O157:H7 in saturated porous media. Water Resour. Res. 2006, 42, 42. [CrossRef]

57. Cai, L.; Tong, M.; Wang, X.; Kim, H. Influence of Clay Particles on the Transport and Retention of Titanium Dioxide Nanoparticles in Quartz Sand. Environ. Sci. Technol. 2014, 48, 7323-7332. [CrossRef]

58. Chen, G.; Liu, X.; Su, C. Transport and Retention of $\mathrm{TiO}_{2}$ Rutile Nanoparticles in Saturated Porous Media under Low-IonicStrength Conditions: Measurements and Mechanisms. Langmuir 2011, 27, 5393-5402. [CrossRef]

59. Choy, C.C.; Wazne, M.; Meng, X. Application of an empirical transport model to simulate retention of nanocrystalline titanium dioxide in sand columns. Chemosphere 2008, 71, 1794-1801. [CrossRef]

60. Solovitch, N.; Labille, J.; Rose, J.; Chaurand, P.; Borschneck, D.; Wiesner, M.R.; Bottero, J.-Y. Concurrent Aggregation and Deposition of $\mathrm{TiO}_{2}$ Nanoparticles in a Sandy Porous Media. Environ. Sci. Technol. 2010, 44, 4897-4902. [CrossRef]

61. Vecchia, E.D.; Luna, M.; Sethi, R. Transport in Porous Media of Highly Concentrated Iron Micro- and Nanoparticles in the Presence of Xanthan Gum. Environ. Sci. Technol. 2009, 43, 8942-8947. [CrossRef]

62. Wang, Y.; Li, Y.; Fortner, J.D.; Hughes, J.B.; Abriola, L.M.; Pennell, K.D. Transport and Retention of Nanoscale $\mathrm{C}_{60}$ Aggregates in Water-Saturated Porous Media. Environ. Sci. Technol. 2008, 42, 3588-3594. [CrossRef]

63. Zeichner, G.; Schowalter, W. Effects of hydrodynamic and colloidal forces on the coagulation of dispersions. J. Colloid Interface Sci. 1979, 71, 237-253. [CrossRef]

64. Wang, D.; Zhang, W.; Zhou, D. Antagonistic Effects of Humic Acid and Iron Oxyhydroxide Grain-Coating on Biochar Nanoparticle Transport in Saturated Sand. Environ. Sci. Technol. 2013, 47, 5154-5161. [CrossRef] [PubMed] 